\title{
A Review of Formal and Informal Regulations in the Nordic Influencer Industry
}

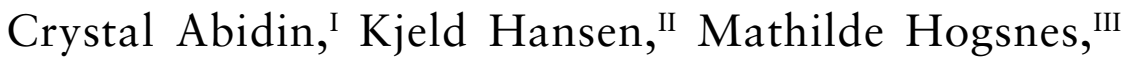 \\ Gemma Newlands, ${ }^{\text {V }}$ Mette Lykke Nielsen, ${ }^{\mathrm{V}}$ \\ Louise Yung Nielsen, ${ }^{\mathrm{VI}} \&$ Tanja Sihvonen ${ }^{\mathrm{VII}}$ \\ ${ }^{\mathrm{I}}$ Curtin University, Australia \\ II Kristiania University College, Norway, \& Copenhagen Business School, Denmark \\ III Kristiania University College, Norway \\ Iv University of Amsterdam, the Netherlands, \& BI Norwegian Business School, Norway \\ v Aalborg University, Denmark \\ VI Roskilde University, Denmark \\ VII University of Vaasa, Finland
}

\begin{abstract}
This article provides a systematic review of laws, guidelines, and best practices related to the Nordic influencer industry as of the year 2020. We highlight some nuanced differences or shortfalls across Denmark, Finland, Norway, and Sweden, and give some policy recommendations to national governments and industry in order to maintain a professional Nordic standard. The article identifies a degree of social, cultural, and economic coherence in the Nordic context that allows for the Danish, Finnish, Norwegian, and Swedish influencer industries to be viewed as a collaborative entity. It then reviews the status of income and tax procedures, and the regulation of commercial disclosures for influencers in the Nordic region. It is hoped that this research contributes to strengthening the integrity and rigour of the Nordic influencer industry to serve as a model for other regional networks of influencers.
\end{abstract}

Keywords: influencer industry, regulation, policy, social media, Nordic media

\section{Introduction}

In April 2017, Fyre Festival, a luxury music festival to be held in the Bahamas, was embroiled in an influencer-related scandal. Specifically, the event, organised by Fyre Media's CEO Billy McFarland and rapper Ja Rule, had employed dozens of prominent American influencers to promote tickets costing up to tens of thousands of US Dollars on Instagram (Bluestone, 2017). However, it was exposed as

Abidin, C., Hansen, K., Hogsnes, M., Newlands, G., Nielsen, M. L., Nielsen, L. Y., \& Sihvonen, T. (2020). A review of formal and informal regulations in the Nordic influencer industry. Nordic Journal of Media Studies, 2, 71-83. https://www.doi.org/10.2478/njms-2020-0007 
fraudulent for failing to provide already paid-for goods and services to attendees, and because contracted influencers had promoted deceptive marketing and did not disclose their paid advertising on social media (Levin, 2017). The Fyre Festival scandal became a critical turning point in the global influencer industry and sparked heated debates about the lack of laws and regulations governing influencers (Higgins, 2019). Following this, several international institutions and organisations pressed for and developed more stringent and standardised rules around influencer advertising (Abidin, 2018: 84), including the European Advertising Standards Alliance (2018) and the International Council for Ad SelfRegulation (2018).

Evidently, issues around influencers' commercial disclosure and tax declaration practices are important, especially as non-disclosure and tax evasion can lead to the loss of credibility among influencers, clients, and in the industry as a whole (Abidin \& Ots, 2016). In the wake of recent pressures to professionalise and standardise guidelines and policies in the influencer industry worldwide, this article is the first attempt to consolidate and posit the notion of a Nordic influencer industry. The article contributes to the (slow) growing literature on Nordic influencer cultures focusing on, for instance, Danish online celebrities and wordof-mouth marketing (Sørensen, 2010); Swedish bloggers and their communication practices with readers (Lövheim, 2012); the culture of Norwegian blog celebrities (Bakke, 2017); and Finnish lifestyle vlogging and girl friendships (Reinikainen et al., 2020). Much of the academic literature on influencers originated in studies on microcelebrity, which is a practice and status wherein users employ the affordances of the Internet to fashion themselves into online celebrities through self-branding techniques and by imagining their prospective online audiences as fans (Marwick, 2013; Senft, 2008). More contemporary studies examined influencers who adopt "vocational, sustained, and highly branded" (Abidin, 2018: 71) forms of microcelebrity, able to convert and carry value across their "data streams" (Hearn \& Schoenhoff, 2015), and who cultivate followers by narrating their personal lives to engage with audiences and embed sponsored content in advertorials (Abidin, 2015).

In this article, we identify a degree of social, cultural, and economic coherence in the Nordic context that allows for the Danish, Finnish, Norwegian, and Swedish influencer industries to be viewed as a collaborative entity, especially as they are collectively experiencing unprecedented growth in the sector. Drawing from a systematic review of laws, guidelines, and best practices through publicly available policy documents, corporate documents, industry recommendations, and norms in the Nordic languages and English, conducted between June and December 2019, we then posit that the Nordic influencer industry evidences some regional benchmarks in relation to influencer income and taxes, and the regulation of their commercial disclosures. In particular, we highlight some nuanced differences or shortfalls across the Nordic countries, in the hopes that specific national governments and industry will be able to address these gaps, maintain a 
professional Nordic standard, and serve as a model for other regional networks of influencer industries.

\section{The Nordic context}

The Nordic countries appear to share some values and norms that have shaped the region's influencer industry. Distinctly Nordic aspects of the influencer industry in this part of the world include institutional, systemic, and cultural norms. Personal income and tax information are relatively transparent and accessible by the general public, thus facilitating calls for greater economic transparency in the influencer industry to take root and be effected swiftly. Nordic countries are also among the top ranked countries for gender balance in the workplace and for equal pay, thus allowing for the usually feminised influencer industry (Abidin, 2016; Duffy, 2017) to be taken seriously as a profession. Government-funded research is also paying attention to how influencers impact young people and various social causes. Across the Nordic countries, there are various collaborations and partnerships among influencer agencies (e.g., Troot ${ }^{1}$ ), influencer networks (e.g., United Screens ${ }^{2}$ ), public relations firms (e.g., PR Nordic ${ }^{3}$ ), and media companies that have been jointly owned and operated, fostering a degree of regional standardisation. The small population size and cultural homophily across Nordic countries enables us to argue for a distinct Nordic culture of influencer industry practices that are not yet as prominent in other regional economies (i.e., the Southeast Asian influencer industry and North American influencer industry). In this section, we aggregate some of the key institutional, cultural, and social practices across four countries to evidence that the influencer industry has grown to be a bona fide economy in the Nordic region.

In Denmark, the 14 largest influencer agencies doubled their financial turnover between 2016 and 2018, reporting over DKK 108 million (The Agency for Culture and Palaces, 2019). In 2016, these 14 influencer agencies had 37 full-time employees, increasing to 76 in 2018 (Agency for Culture and Palaces, 2019). However, a country-specific shortfall is that the Danish market has not been systematically surveyed, and it is presumed that there are large amounts of unreported economic activity and transactions (Roliggaard, 2019). In July 2019, one of the most well-known Danish influencers shared a suicide note on Instagram, instigating a huge debate about the ethical responsibility of influencers towards followers and users, but focusing mainly on platforms' responsibility (Gjerding, 2019). NGOs and researchers working with suicide, mental health, and children have reported that such content from influencers can have a negative impact on followers if it is not quickly removed (Roliggard et al., 2019). Subsequently, the Minister of Children and Education encouraged influencers to follow the ethical code of conduct of the mainstream press: to not publicise reports on suicides or suicide attempts unless it is of interest to the public (Dalgas, 2019).

In Finland, the influencer industry has evolved from its original focus on individual platforms such as blogs (see KKV, 2013) and YouTube to a multi-platform, 
media-mix approach. According to a survey by the network of marketers in Finland, Marketing Finland (Mainostajien liitto, 2018), over 72 per cent of Finnish advertisers have tried influencer marketing. However, current regulations still specifically govern advertising on some popular platforms (i.e., YouTube) but not others, which surfaces the need for a common set of rules and ethical guidelines. The popular press (e.g., Pallaste, 2017) and publications from industry (e.g., IAB Finland, 2019) have outlined different types of marketing and various contexts. There are regulatory frameworks initiated both by the industry (e.g., Ping Helsinki, 2020) and public institutions (Finnish Competition and Consumer Authority, 2019), promoting transparent communication about commercial cooperation in targeted influencer marketing.

The Norwegian influencer industry has grown rapidly, becoming a significant partner to many large companies and advertisers. The influencer and content-marketing industry now takes up approximately NOK 4 billion of the NOK 20 billion spent domestically on advertising and media marketing (ANFO, 2019). However, the influencer industry is criticised for its lack of structure, non-transparent pricing systems, and limited documentation of its marketing effects. Influencers, influencer networks, advertisers, and social networks have recently adopted a more proactive role, taking it upon themselves to contribute constructively to establishing clear structures, rules, and frameworks (Drange, 2018). In Norwegian media, influencers' societal roles, contributions, and responsibilities have been debated intensely. In particular, influencers are heavily criticised for encouraging beauty pressure and body dissatisfaction among young girls (Forbrukertilsynet, 2018)

Finally, the Swedish media industry is increasingly incorporating influencer marketing as a staple in their advertising repertoire, with the annual domestic spending on Internet advertising taking up 12.5 per cent of the SEK 81,963 million budget in 2018 (IRM, 2018). Two surveys in 2019 found that Swedish influencers had higher average engagement rates than their Nordic neighbours (Relatable, 2019) and that the average minimal influencer income in Sweden is SEK 1,500-100,000 (Tankovska, 2019). In response, Stockholm-based streaming platform Starflow is developing an influencer-specific cryptocurrency known as Starcoin to enable influencers to "safeguard their digital identities" (Bitcoin PR Buzz, 2018), although little is known about the reliability and governance of these emergent initiatives. Swedish influencers have also reportedly contributed to the rise in veganism (Brodala, 2018), environmental sustainability (Joosse \& Brydges, 2018), and fashion recycling (Köhler, 2018). But these small “wins” may distract from the larger need to interrogate the damage of mass consumption encouraged by influencers in the first place.

Across the board, the Nordic countries are similarly experiencing an unprecedented growth in influencer marketing and integrating into their advertising repertoire. Influencers are also generating impact in a range of social issues, from mental health to environmentalism. However, given the quick growth, each country market still has an institutional shortfall to address: Denmark and Norway 
lack a rigorous system for accounting for commercial activity and pricing systems; Finland and Norway need to further standardise their rules and ethics across online advertising platforms and genres; and Sweden requires more understanding of and regulatory guidance for its emergent influencer currency models. In the next section, we examine more deeply the existing income and tax models in the Nordic influencer industry to identify potential benchmarks for the region based on the best practices across the country markets.

\section{Nordic influencer income and taxes}

Drawing on guidelines and regulations for income tax declarations of each country market, in this section we posit four benchmarks for the Nordic influencer industry based on the highest standing currently available in the region.

First, the Nordic threshold for being considered a "career" influencer is the amount of monetary income earned. Finland has a particularly good model for working through the ambiguous dichotomy between hobbyist and career influencers. Many self-identified hobbyist influencers in Finland usually do not engage in tax declarations. However, if the monetary compensation from their social media activity becomes substantial, they will be classified as self-employed entrepreneurs. At this point, Finnish influencers may opt for the freelancer-verokortti [freelancer's tax card], which allows some flexibility in terms of employment relationships and earnings. They can also adapt as kevytyrittäjä [light entrepreneurs] (see Vero, 2019) through specific services like Ukko, which allows individuals to outsource their paperwork. Similarly, the Norwegian Tax Administration deems that influencers are conducting commercial activity if it "is carried on at own expense and risk", "is expected to have a certain scope and duration", and "is likely to generate a profit" (Skatteetaten, 2019: para. 3). In Sweden, the guidelines are more clear, with the Swedish Tax Agency announcing in April 2019 that all influencers earning more than SEK 19,247 in 2018 must file income tax declarations (Bloomberg Tax, 2019). Foreign influencers who are contracted by Swedish companies must also pay special income taxes (Boostified, 2019). Currently, Denmark has no income thresholds, but Danish bloggers with a yearly income of DKK 150,000 or below are not considered to be independent business owners, but freelancers, according to a 2016 ruling (Danish Customs and Tax Administration, 2016).

Second, tax laws for Nordic influencers are still under development, but currently require regulations and definitions to be presented in clear, non-expert formats that are accessible to the general public. The Norwegian Tax Administration has well-defined, adjusted, and clearly presented rules and regulations for the taxation of "blogging and social media", which appear separately on their website (Skatteetaten, 2019). However, there is a persistent grey zone around the new and very young hobbyist influencers in Norway who are often unfamiliar with the rules and regulations of taxation. For example, they might not be aware that they have progressed in their hobbies and become professional influencers, 
finding it difficult to discern whether a gift has been given privately or professionally, and they might find it difficult to regard unwanted gifts as a taxable income (Ekeberg, 2019). Likewise, Danish influencers are often described as working in a grey area, where it can be difficult to understand tax rules (Vestergaard, 2019a). In March 2019, the former Danish Minister for Taxation asked his officials to make the tax rules clearer for influencers (Vestergaard, 2019b), although as of late 2019, this has not yet been implemented. This issue of accessibility must be addressed by all country markets.

Third, Nordic influencers must disclose non-monetary gifts in their tax claim. In all four Nordic countries studied, gifts or goods of value that influencers received - whether solicited or not - must be declared as income (Skatteetaten, 2019; Danish Customs and Tax Administration, 2019). Under Danish tax law, the basic principle is that citizens must pay taxes every time they have an "economic advantage", regardless of whether this is in the form of a fee, gifts, or goods (Vestergaard, 2019a). In Sweden, even if influencers have chosen not to promote received goods on social media, or give away products to followers, the act of having received something must be declared as income (Boostified, 2019) unless the goods are returned to sponsors (Bloomberg Tax, 2019).

Fourth, Nordic industry institutions are supplementing government provisions by acting as intermediaries to publicise, formalise, and resolve income issues. Norwegian professional influencers are commonly managed by specialist organisations or networks, which consequently manage their tax returns and ensure that taxes are paid correctly. Influencers can also claim a tax deduction on necessary items such as Internet connections, smartphones, and photographic equipment (Skatteetaten, 2019). In Sweden, agencies and advertising firms brokering engagements between influencers and brands have compiled accessible "explainers" for both parties to understand taxation rules (e.g., Boostified, 2019). In Finland, although it has been estimated that, as of 2019, there are only 50-100 influencers who make a decent-to-substantial living through their social media work (Manifesto, 2019), the total number of those who obtain some revenue from sponsorship deals, ads, or corporate gifts is likely to be in the thousands. In the absence of any formal industry support, influencer income is frequently discussed on Finnish job-seeking portals (Komulainen, 2018) and in traditional journalism (Tiainen, 2019). In Denmark, dedicated influencer agencies assist influencers with their taxes, but are usually not contractually required to do so. Lawyers and accountants also offer (paid) services to influencers and their commercial partners (e.g., Jacobsen, 2017).

Across the board, some Nordic countries already have the skeletal structures in place for moderating the hobbyist-career influencer threshold, presenting tax laws in clear language to the public, stipulating that non-monetary gifts providing economic advantage are considered income, and collaborating with willing industry partners to communicate guidelines to influencers and clients. Alongside improving the definitional boundaries of these regulations, we suggest that there should also be an effective system for enforcing these rules and penalising flouters. 
We encourage each national government to ensure that these systems are routinely updated for clarity and to complement the vernacular activity happening on the ground, especially in light of the spike of newer and younger influencer aspirants. As larger numbers of teenagers and young people dabble in influencer commerce, the distinction between hobbyist and career influencers may need to be stricter, while communication of laws ought to be more age-accessible. We recommend that authorities also consider that clients may disadvantage influencers by compensating them with more gifts rather than monetary payments, and if such strategies take place at scale, industry partners are encouraged step in to regulate the economy and oversee the welfare of their (increasingly young) influencers as well.

\section{Nordic regulation of influencer disclosures}

While income and tax regulations may seem more stringent and consistent, the ever-evolving and emergent social media platforms and formats make it much more difficult to police the presentation of influencers' advertising disclosures. As such, here we consider the Nordic specificities around laws, guidelines, and best practices pertaining to the disclosure of sponsored content in the influencer industry, paying special attention to the precise formatting required of influencers' sponsored posts.

First, Nordic influencers are required by law to mark all content with commercial intent as advertisements, including "hidden" or "subliminal" advertising. In Sweden, disclosure regulations were first released in the early-2010s (Sveriges Annonsörer, 2015) with vernacular advertising disclosure strategies recommended by industry organisations such as Influencers of Sweden (Hörnfeldt, 2016). But from the late-2010s, new stricter laws were introduced across the Nordic calling upon influencers to disclose when the content they post online has commercial intent (e.g., Forbrukertilsynet, 2017). This regulation extends to hidden or subliminal advertising where the commercial intent may not be obvious to everyday viewers (Forbrugerombudsmanden, 2017; Kosumentverket, 2019a). Advertisers on social media have also been tasked with meeting the guidelines for traditional media such as television and magazines (Konsumentverket, 2019a).

Second, Nordic influencers must abide by specific presentation and aesthetic guidelines when signposting sponsored content. In general, influencers must unambiguously and clearly label their sponsored content, paying attention to large fonts and placement in prominent positions - such as being superimposed onto the image or video or in the beginning of textual captions - that are recognisable by viewers (Forbrukertilsynet, 2019; Medietilsynet, 2019). For YouTube and video content, disclosures must be placed at the start of the video (Forbrukertilsynet, 2019; Konsumentverket, 2019a; Medietilsynet, 2019) in clear language. It is insufficient to merely verbally mention in the voiceover that the video is sponsored, add tags, or post ambiguous abbreviations like "ad" in the captions (Finnish Competition and Consumer Authority, 2019; Konsumentverket, 2019a). 
It is also insufficient for influencers to use the platform's in-app or native labelling tool or sticker, such as Instagram's "Paid promotion" tag or YouTube's "Contains sponsored content" button (Finnish Competition and Consumer Authority, 2019).

Third, a network of Nordic stakeholders - influencers, advertisers, agencies, and ombudsmen - share the responsibility for keeping best practices in the influencer industry. In addition to the consumer ombudsman, tax authorities, and advertising watchdogs cited in this article, Nordic influencers are advised by industry to partner with advertising clients (Haugseth, 2018; Konsumentverket, 2019a) and their agencies to comply with regulations. Some Nordic countries have specific ombudsmen, such as the Finnish Consumer Ombudsman (Finnish Competition and Consumer Authority, 2019), the Norwegian Consumer Authority (Haugseth, 2018), the Swedish Consumer Agency (Konsumentverket, 2019a), and the Swedish Advertiser's Committee for Public Relations (Sveriges Annonsörer, 2015). In addition, there are also various statutes like the Norwegian Marketing Control Act (Haugseth, 2018) and official guiding sheets (Konsumentverket, 2019b) prepared for influencers, alongside intermediaries who can broker interpretations and company-influencer engagements to ensure compliance.

Fourth, some influencers and companies are still skirting the Nordic regulations, as current ones are not yet strictly enforced among influencers and clients. Despite the best efforts of state boards, industry ombudsmen, and influencers themselves, some influencers and clients still flout the rules. For instance, in August 2019, four Danish influencers were reported to the police for using "unclear wording" such as "ad" or "spons" instead of the Danish words "reklame" or "annonce", for tagging commercial partners without explicitly stating the commercial activity, and for distributing content from one social media platform to another without disclosing the commercial activity (Forbrugerombudsmanden, 2019). In Sweden, some rule-breaking influencers have been penalised, while others have slipped under the radar (e.g., Garson, 2019). In Norway, some advertisers have sent out free products while closing their eyes and hoping that influencers will promote their wares without a formal agreement (Haugseth 2018). While there are some regulations and guidelines in place, there is not yet an effective way of ensuring their compliance.

Given that many Nordic influencers share followers and cross-advertise for clients in the region, we recommend the institution of a Nordic-wide system for enforcing rules and reporting influencers and clients who flout them. It is important to hold clients partly responsible and regulate the advertising demands they place on influencers, in order to stop "backdoor" and "under the table" innovations before they start. In the long run, these collective initiatives will raise the overall ethical and professional standard of the Nordic influencer industry and encourage international clients and investors to tap into this ethical and rigorous market. 


\section{Conclusion}

Considering the global interest in regulation of influencer taxes and ad disclosures, this article provides a review of the current rules, regulations, and best practices promoted by governments, advertising boards, and influencer agencies in the Nordic region, and identifies areas with shortfalls or points for improvement. Compared to other parts of the world, these movements were perhaps more smoothly put in place considering the shared Nordic values and norms around income and tax transparency, gender parity in the workplace, and intra-Nordic business collaborations. Given the culture of institutional transparency in Nordic corporate cultures, many of the recommendations focus on formally instituting standards of integrity among influencers and advertisers.

The current guidelines in the Nordic influencer industry model focus on clear, legible, and accessible distinctions for several definitions: cash payments or gift incentives; hobbyist beginnings or professional careers; appearances of advertising or intentions of advertising; and procedural understanding of regulations or practical enactment of regulations. Apart from government laws and ombudsman regulations, several industry entities have taken the initiative to further standardise best practices in the Nordic influencer industry. Still, despite some regularity and agreement across the Nordic statutes, guidelines, and regulations, we have highlighted in the sections above the shortfalls specific to country markets and the Nordic region as a whole. Having reviewed the best practices in the region, we have also suggested that there should be an effective Nordic-wide system for standardising regulations, enforcing rules, and penalising flouters. We recommend that each of the Nordic governments share a stake in ensuring that their national systems are routinely reviewed to maintain the Nordic standard of influencer commerce, and updated to keep abreast of the fast-changing developments among young influencers and followers in the industry.

However, we also note that to avoid over-generalising and erasing the rich cultural specificities of the country markets under the Nordic umbrella, further research should be attentive to the current sociocultural issues that have shaped each market. For instance, Danish influencer agencies are concerned about the agency of influencers as "independent media houses" (Richardt, 2019). Thus, while they do provide information about the rules of disclosure, commerce, and tax, they are unable to strictly enforce any rules. The most well known Finnish influencers are under 25 - or even teenagers - with even younger followers. As such, Finnish influencer networks have focused their energies on educational campaigns about the spread of disinformation and manipulation on social media (Koskinen, 2018). The Norwegian grey zones of interpretation and enforcement have reduced the efficacy of various initiatives. In response, the Norwegian Media Businesses' Association and the interest organisation for Norwegian Advertisers known as ANFO have established trust and credibility as key concepts for the industry (Drange, 2018). In Sweden, influencer grassroots groups are keen to peer 
review and peer certify each other. As such, ground-up initiatives have included events and pedagogical workshops, member subscriptions, consultancy services, and a kvalitetsstämpel [stamp of quality] to certify that an influencer's channel has been endorsed by the network (Influencers of Sweden, 2019). We hope that this Review of the Nordic Influencer Industry will serve as a springboard for further research into the institutional, cultural, and social lives of this blooming economy.

\section{Notes}

1. https://trootgroup.com

2. https://unitedscreens.com

3. https://prnordic.com

\section{References}

Abidin, C. (2015). Communicative $\bullet$ intimacies: Influencers and perceived interconnectedness. Ada: A Journal of Gender, New Media, \& Technology, 8. https://www.doi.org/10.7264/N3MW2FFG

Abidin, C. (2016). “Aren't these just young, rich women doing vain things online?": Influencer selfies as subversive frivolity. Social Media + Society, 2(2), 1-17. https://doi. org/10.1177/2056305116641342

Abidin, C. (2018). Internet celebrity: Understanding fame online. Bingley, UK: Emerald Publishing.

Abidin, C., \& Ots, M. (2016). Influencers tell all? Unravelling authenticity and credibility in a brand scandal. In M. Edström, A. T. Kenyon, \& E-M. Svensson (Eds.), Blurring the lines: Market-driven and democracy-driven freedom of expression (pp. 153-161). Gothenburg: Nordicom, University of Gothenburg.

Agency for Culture and Palaces. (2019). Kort nyt: Influencer-bureauer [Brief news: Influencer agencies]. Retrieved September 5, 2019, from https://mediernesudvikling.slks.dk/fileadmin/user_upload/ dokumenter/medier/Mediernes_udvikling/2019/Kort_nyt/Influencer-virksomheder/Kort_Nyt_-_Influencer-bureauer.pdf

Annonsørforeningen (ANFO). (2019). Content marketing-markedet i Norge: 4 milliarder [Content marketing-market in Norway: 4 billion]. Retrieved September 1, 2019, from https://www.anfo. no/content-marketing-markedet-i-norge-4-milliarder

Bakke, M. A. (2017). Celebrity is what celebrity does. [Master's thesis, University of Oslo, Norway].

Bitcoin PR Buzz. (2018, March 13). Influencer economy solution Starflow is Sweden's first token generation event. Coin Idol: Blockchain News Outlet. Retrieved October 23, 2019, from https:// coinidol.com/starflow-sweden-first-token-generation-event/

Bloomberg Tax. (2019, April 23). Sweden tax agency announces income tax declaration for social media influencers, YouTubers, online gamers. Retrieved October 23, 2019, from https://news. bloombergtax.com/daily-tax-report-international/sweden-tax-agency-announces-income-tax-declaration-for-social-media-influencers-youtubers-online-gamers

Bluestone, G. (2017, May 3). Fyre Festival organizers blew all their money months early on models, planes, and yachts. Vice News. Retrieved October 23, 2019, from https://www.vice.com/en_us/ article/7xwabq/fyre-fest-organizers-blew-all-their-money-months-early-on-models-planes-andyachts

Boostified. (2019). Do you get headaches from all of the taxation rules? Retrieved October 23, 2019, from https://boostified.com/skattefragorinfluencers/\#1542692933183-4aa83ae9-7dc9

Brodala, J. (2018, April 17). Why this Scandinavian country is consuming less meat. The Culture Trip. Retrieved October 23, 2019, from https://theculturetrip.com/europe/sweden/articles/thisis-why-sweden-is-consuming-less-meat/

Dalgas, J. (2019, July 9). Minister efter Fie Laursen-sag: »Dette ville have voret en beskyttelse af både hende og hendes følgere" [Minister on Fie Laursen case: "This would have been a protection

\section{Acknowledgements}

We would like to acknowledge The Danish Working Environment Research Fund, The Research Council of Norway (Project Code: 275347), Handelsrådets, and the MMTC at Jönköping University, Sweden for supporting portions of this research. 
for both her and her followers"]. Berlingske. Retrieved September 5, 2019, from https://www. berlingske.dk/samfund/minister-efter-fie-laursen-sag-dette-ville-have-vaeret-en-beskyttelse-af

Danish Customs and Tax Administration. (2016). Ikke selvstondig erhvervsdrivende ved aktivitet med at drive en blog [Running a blog is not being self-employed]. Retrieved February 19, 2020, from https://www.skat.dk/skat.aspx?oid=2233149

Danish Customs and Tax Administration. (2019). Gaver til bloggere, influencere, foredragsholdere og andre [Gifts for bloggers, influencers, speakers, and others]. Retrieved September 6, 2019, from https://skat.dk/skat.aspx?oid=2234842

Drange, J. M. (2018, December 20). Etablerer ny organisasjon for influencer-markedsføring [Establishing a new influencer-marketing organisation]. Kampanje. Retrieved September 1, 2019, from https://kampanje.com/markedsforing/2018/12/anfo-oppretter-ny-influencer-organisasjon/

Duffy, B. E. (2017). (Not) getting paid to do what you love. New Haven, Connecticut: Yale University Press.

Ekeberg, I. (2019, July 30). Influensere mottar drøssevis av skattepliktige "gaver»: - Jeg kunne ha levd gratis en dag om jeg ville [Influencers receive dozens of taxable "gifts": "I could have lived for free one day if I wanted to"]. Dagens Næringsliv. Retrieved October 27, 2019, from https:// www.dn.no/markedsforing/influenserne/markedsforing/digital-markedsforing/influensere-mottardrossevis-av-skattepliktige-gaver-jeg-kunne-ha-levd-gratis-en-dag-om-jeg-ville/2-1-633530

European Advertising Standards Alliance. (2018, December 10). EASA best practice recommendation on influencer marketing. Retrieved April 8, 2020, from https://www.easa-alliance.org/productsservices/publications/best-practice-guidance

Finnish Competition and Consumer Authority. (2019, August 30). Influencer marketing in social media. Retrieved October 27, 2019, from https:/www.kkv.fi/en/decisions-and-publications/ publications/consumer-ombudsmans-guidelines/by-subject/influencer-marketing-in-social-media/

Forbrugerombudsmanden. (2017, December 14). Gode råd til influenter om skjult reklame [Tips for influencers on hidden advertising]. Retrieved September 6, 2019, from https://www.forbrugerombudsmanden.dk/media/49742/17-10423-20-gode-raad-til-influenter-om-skjult-reklame_mbilleder-3044183_1_1.pdf

Forbrugerombudsmanden. (2019, August 13). Forbrugerombudsmanden politianmelder influenter for skjult reklame [The consumer ombudsman reports influencers to the police for covert advertising]. Retrieved September 5, 2019, from https://www.forbrugerombudsmanden.dk/nyheder/ forbrugerombudsmanden/pressemeddelelser/2019/forbrugerombudsmanden-politianmelder-influenter-for-skjult-reklame/

Forbrukertilsynet. (2017, May 30). Vil fjerne skjult reklame i sosiale medier [Will remove hidden advertising in social media]. Retrieved August 1, 2019, from https://www.forbrukertilsynet.no/ fjerne-skjult-reklame-pa-sosiale-medier

Forbrukertilsynet. (2018, June 8). Annonsørene må ta ansvar [Advertisers must take responsibility]. Retrieved September 1, 2019, from https://www.forbrukertilsynet.no/annonsorene-ma-ta-ansvar

Forbrukertilsynet. (2019). Forbrukertilsynets veileder for merking av reklame i sosiale medier [The Consumer Authority's guidance on labelling advertising in social media]. Retrieved August 1, 2019 https:/www.forbrukertilsynet.no/lov-og-rett/veiledninger-og-retningslinjer/veiledningreklame-some

Garson, J. (2019, May 7). How to be an influencer and not get sued. Forbes. Retrieved October 23, 2019, from https:/www.forbes.com/sites/jackgarson/2019/05/07/how-to-be-an-influencer-andnot-get-sued/\#4e093fd9645a

Gjerding, S. (2019, July 10). Instagram under pres efter stor eksponering af Fie Laursens selvmordsbrev [Instagram under pressure after big exposure of Fie Laursen's suicide letter]. Information. Retrieved September 5, 2019, from https://www.information.dk/indland/2019/07/instagram-presstor-eksponering-fie-laursens-selvmordsbrev

Haugseth, E. (2018, June 8). Annonsørene må ta ansvar [Advertisers must take responsibility]. Dagens Næringsliv. Retrieved September 1, 2019, from https:/www.dn.no/innlegg/pavirker/markedsforing/sosiale-medier/annonsorene-ma-ta-ansvar/

Hearn, A., \& Schoenhoff, S. (2015). From celebrity to influencer. In P. D. Marshal, \& S. Redmond (Eds.), A companion to celebrity (pp. 194-212). New Jersey: John Wiley \& Sons.

Higgins, M. (2019, March 25). Fyre Festival aftermath: New rules for influencers? University of Cincinnati Law Review. Retrieved October 23, 2019, from https://uclawreview.org/2019/03/25/ fyre-festival-aftermath-new-rules-for-influencers/

Hörnfeldt, L. (2016, January 24). Rekommendationer: Annonsmärkning av samarbeten på blogg, YouTube och Instagram [Recommendations: Advertising tagging of collaborations on blogs, 
YouTube, and Instagram]. Influencers of Sweden. Retrieved October 23, 2019, from https:// influencersofsweden.se/rekommendationer-annonsmarkning-blogg/

IAB Finland (2019). Vaikuttajamarkkinoinnin opas [Influencer marketing guide]. Retrieved October 27, 2019, from https://www.iab.fi/media/pdf-tiedostot/standardit-ja-oppaat/iab_vaikuttajamarkkinoinnin_opas_02_2019.pdf

Influencers of Sweden. (2019). Vill du också leva din dröm? [Do you want to live your dream?] Retrieved October 23, 2019, from https://influencersofsweden.se/

Institutet för reklam- och mediestatistik (IRM). (2018). Marketing Investment Sweden 2018. Retrieved October 23, 2019, from https://www.irm-media.se/in-english/marketing-investment-sweden-2018

International Council for Ad Self-Regulation. (2018). Guidelines for social media influencers. Retrieved October 23, 2019, from https://icas.global/advertising-self-regulation/influencer-guidelines/

Jacobsen, L. (2017, September 20). Depechen-artikel: Skat for bloggere [Depechen article: Tax for bloggers]. BDO Denmark. Retrieved February 19, 2020, from https://www.bdo.dk/da-dk/ faglig-info/depechen/depechen-artikler-2017/skat-for-bloggere

Joosse, S., \& Brydges, T. (2018). Blogging for sustainability: The intermediary role of personal green blogs in promoting sustainability. Environmental Communication, 12(5), 686-700. https://doi. org/10.1080/17524032.2018.1474783

KKV (Finnish Consumption and Consumer Authority). (2013, November 18). Consumer ombudsman: Hidden advertising forbidden in blogs as well. Retrieved October 27, 2019, from https://www. kkv.fi/en/current-issues/press-releases/2013/consumer-ombudsman-hidden-advertising-forbidden-in-blogs-as-well/

Komulainen, V. (2018, June 8). Sita Salminen tekee YouTube-videoita työkseen - mutta miten tubettamisesta tehdään ammatti? [Sita Salminen makes YouTube videos for work - but how does YouTubing become a profession?] Duunitori. Retrieved October 27, 2019, from https://duunitori. fi/tyoelama/sita-salminen

Konsumentverket. (2019a, June 12). Marknadsföring i sociala medier och bloggar [Marketing in social media and blogs]. Konsumentverket. Retrieved October 23, 2019, from https://www. konsumentverket.se/for-foretag/marknadsforing/marknadsforing-i-sociala-medier-och-bloggar/

Konsumentverket. (2019b). Vägledning om marknadsföring i bloggar och andra sociala medier [Guidance on marketing in blogs and other social media]. Konsumentverket. Retrieved October 23, 2019, from https://www.konsumentverket.se/contentassets/46dcfbc6db1148918b23e9fb6acde3 cd/vagledning_om_marknadsforing_i_bloggar-201511-tillganglig-konsumentverket.pdf

Koskinen, T. (2018, August 10). Somevaikuttajat mukaan torjumaan valeuntisia [Influencers to be involved in fighting fake news]. Ping Helsinki. Retrieved October 27, 2019, from https://pinghelsinki.fi/somevaikuttajat-mukaan-torjumaan-valeuutisia/

Köhler, M. (2018). Reusing garments: An investigation of influencers to return used garments. [Master's thesis, University of Borås, Sweden]. Retrieved October 23, 2019, from http://www. diva-portal.org/smash/record.jsf?pid=diva2\%3A1232468\&dswid=-6511

Levin, S. (2017, May 2). Fyre festival: Social media 'influencers' traded posts for lavish perks. The Guardia. Retrieved October 23, 2019, from https://www.theguardian.com/culture/2017/may/01/ fyre-festival-social-media-influencers-paid-content

Lövheim, M. (2012). Negotiating empathic communication: Swedish female top-bloggers and their readers. Feminist Media Studies, 13(4), 613-628. https://doi.org/10.1080/14680777.2012.659672

Mainostajien liitto. (2018, April). Mainostajien liiton pulssikysely jäsenilleen [Snapshot survey to the members of the Association of Finnish Advertisers]. Ping Helsinki. Retrieved October 27, 2019, from https://pinghelsinki.fi/wp-content/uploads/2018/05/PingMetrics_2018.pdf

Manifesto. (2019, September 3). Somevaikuttaja 2019: Instagram vahvistunut entisestään, myös podcast nousussa [Social Media Influencer 2019: Instagram stronger than ever, also podcasts on the rise]. Retrieved October 27, 2019, from https://www.dropbox.com/s/0o5amosog $9 \mathrm{p} 5 \mathrm{vmc} /$ Somevaikuttajabarometri2019.pdf? dl=0

Marwick, A. E. (2013). Status update: Celebrity, publicity, and branding in the social media age. New Haven, Connecticut: Yale University Press.

Medietilsynet. (2019). Norwegian media authority: Reklame I Youtube-videoer og andre videoblogger: Slik merker du videoene [Advertising in YouTube videos and other video blogs: How to label the videos]. Retrieved October 30, 2019, from https://medietilsynet.no/mediebransjen/ reklame/\#anchor_5882

Pallaste, T. (2017, July 1). Ammattijulkkis Maisa Torppa kertoo, mitä kuuluisunden kulisseissa tapahtuu: Luksuselämän esittämistä, lapsen piilottelua ja mainosalustana toimimista [Professional celebrity Maisa Torppa explains what happens behind the scenes: Performing a luxury lifestyle, 
hiding the child, and acting as an advertising platform]. Helsingin Sanomat. Retrieved October 27, 2019, from https://www.hs.fi/kuukausiliite/art-2000005272622.html

Ping Helsinki. (2020). Ping ethics. Retrieved October 27, 2019, from http://pingethics.fi/en/

Reinikainen, H., Munnukka, J., Maity, D., \& Luoma-aho, V. (2020, January 9). 'You really are a great big sister' - parasocial relationships, credibility, and the moderating role of audience comments in influencer marketing. Journal of Marketing Management. Advance online publication. https:// doi.org/10.1080/0267257X.2019.1708781

Relatable. (2019). Engagement rate benchmark on Instagram by leading global influencer marketing agency Relatable. Retrieved October 23, 2019, from https://docsend.com/view/2jqgb6x?_s=y91tbwqzxp1af3mkqfgm

Richardt, M. (2019, March 25). Bloggeren Signe viser sine gaver frem og betaler sin skat [The blogger Signe shows off her gifts and pays her taxes]. DR Nyheder. Retrieved September 6, 2019, from https://www.dr.dk/nyheder/indland/bloggeren-signe-viser-sine-gaver-frem-og-betaler-sin-skat

Roliggaard, S. (2019, February 7). Første kig på influencerøkonomien: Branchen er $i$ massiv vaekst [First look at the influencer economy: The industry is growing massively]. Politiken. Retrieved September 5, 2019, from https://politiken.dk/kultur/art7024470/Branchen-er-i-massiv-v\%C3\%A6kst

Roliggaard, S., Sjöberg, A., \& Maarbjerg Mørk, E. (2019, July 8). Dansk youtubers selvmordsbrev gik viralt blandt tusinder af unge med Instagrams accept: Burde vere fjernet, siger rådgivningslinje [Danish YouTuber's suicide note went viral among thousands of young people with Instagram's approval: It should have been removed, says suicide hotline]. Politiken. Retrieved September 5, 2019, from https://politiken.dk/kultur/medier/art7289355/Burde-v\%C3\%A6re-fjernet-siger$\mathrm{r} \% \mathrm{C} 3 \% \mathrm{~A} 5$ dgivningslinje

Senft, T. M. (2008). Camgirls: Celebrity \& community in the age of social networks. New York: Peter Lang.

Skatteetaten. (2019). Blogging and social media. Retrieved October 30, 2019, from https://www. skatteetaten.no/en/person/taxes/get-the-taxes-right/employment-benefits-and-pensions/hobbyodd-jobs-and-extra-income/blogging/

Sveriges Annonsörer. (2015). Rekommendation för dig som arbetar med PR och marknadsföring [Recommendation for those who work with PR and marketing]. Retrieved October 23, 2019, from https://static1.squarespace.com/static/5808d514c534a 5bc2dfb527f/583b045e91b186a2 ee00ae4c/583b053e91b186a2ee01f579/1480262974850/rekommendationer_for_dig_som_arbetar_med_pr_och_marknadsforing_2015.pdf?format=original

Sørensen, A. C. (2010). Online word of mouth: A process model of online word of mouth. [Master's thesis, Copenhagen Business School, Denmark].

Tankovska, H. (2019, April 10). Minimum income of Instagram influencers in Sweden 2019, by category. Statista. Retrieved October 23, 2019, from https://www.statista.com/statistics/991882/ minimum-income-of-instagram-influencers-in-sweden-by-category/

Tiainen, A. (2019, August 15). Pinkku Pinsku, Herba ja munt tubettajat kertovat, mitä Youtubessa ei kannata tehdä - ja miten tullaan suosituksi [Pinkku Pinsku, Herba, and other YouTubers explain what you shouldn't do on YouTube]. Helsingin Sanomat. Retrieved October 27, 2019, from https://www.hs.fi/teknologia/art-2000006205282.html

Vero. (2019). Working through an invoicing service company. Retrieved October 27, 2019, from https://www.vero.fi/en/individuals/tax-cards-and-tax-returns/income/earned-income/employee-or-self-employed/light-entrepreneur/

Vestergaard, N. (2019a, March 25). Skattejurist: Bloggere og influencere skal betale skat af alt [Tax lawyer: "Bloggers and influencers are to pay taxes for everything"]. DR Nyheder. Retrieved September 6, 2019, from https://www.dr.dk/nyheder/penge/skattejurist-bloggere-og-influencereskal-betale-skat-af-alt

Vestergaard, N. (2019b, March 25). Bloggere og youtubere har ikke styr på skatten: Nu skal skatterabat gøre det nemt [Bloggers and YouTubers don't know the tax law: A tax discount will change that]. DR Nyheder. Retrieved September 6, 2019, from https://www.dr.dk/nyheder/penge/ bloggere-og-youtubere-har-ikke-styr-paa-skatten-nu-skal-skatterabat-goere-det-nemt

Copyright: $\odot 2020$ The Author(s) and Nordicom. This is an Open Access article distributed under the terms of the Creative Commons Attribution 4.0 International License (CC BY-NC-ND 4.0). 